\title{
Suppression of growth of A549 lung cancer cells by waltonitone and its mechanisms of action
}

\author{
YI ZHANG ${ }^{1}$, GUO-BIN ZHANG ${ }^{2}$, XIAO-MAN XU ${ }^{3}$, MENG ZHANG ${ }^{1}$, \\ DAN QU ${ }^{3}$, HUI-YAN NIU ${ }^{1}$, XUE BAI $^{1}$, LIANG KAN ${ }^{1}$ and PING HE ${ }^{1}$ \\ ${ }^{1}$ Department of Geriatrics, Shengjing Hospital of China Medical University, Shenyang 110004; \\ ${ }^{2}$ Shenyang Center for Disease Control and Prevention, Shenyang 110004; ${ }^{3}$ Department of Respiratory Medicine, \\ Shengjing Hospital of China Medical University, Shenyang 110004, P.R. China
}

Received April 5, 2012; Accepted May 28, 2012

DOI: $10.3892 /$ or.2012.1869

\begin{abstract}
Natural compounds are a great source of cancer chemotherapeutic agents. Our investigation indicates that waltonitone, a triterpene extracted from medicinal plants, inhibits the proliferation of A549 cells in a concentration- and time-dependent manner. Waltonitone induced apoptosis of A549 cells in a concentration-dependent manner, as determined by fluorescence microscopy and flow cytometry. The apoptosis was accompanied by increased Bax protein levels and decreased Bcl-2 protein levels in A549 cells. Furthermore, the treatment of A549 cells with waltonitone altered the expression of miRNAs. We found that 27 miRNAs were differentially expressed in waltonitone-treated cells, of which 8 miRNAs target genes related to cell proliferation and apoptosis. In summary, our results demonstrate that waltonitone has a significant inhibitory effect on the proliferation of A549 cells. It is possible that upregulation of $\mathrm{Bax} / \mathrm{Bcl}-2$ and regulation of expression of specific miRNAs play a role in inhibition of proliferation and induction of apoptosis in waltonitonetreated cells. Waltonitone can be applied to lung carcinoma as a chemotherapeutic candidate.
\end{abstract}

\section{Introduction}

Lung cancer is one of the most common human cancers and the leading cause of cancer death worldwide $(1,2)$. At present, the treatment of lung cancer mainly includes surgery, radiotherapy and chemotherapy. Chemotherapy plays an important role in the treatment of lung cancer, but it is limited to a significant extent by its toxicities, side effects and drug resistance $(3,4)$.

Correspondence to: Dr Ping He, Department of Geriatrics, Shengjing Hospital of China Medical University, 36 Sanhao Road, Shenyang 110004, P.R. China

E-mail: cmu2h@hotmail.com

Key words: waltonitone, miRNAs, lung cancer A549 cells, apoptosis
The mortality in lung cancer patients remains high and the 5 -year overall survival in many countries generally is $<15 \%$ (5). Therefore, it is necessary to search for drugs capable of preventing and treating lung cancer and other malignancies. Recently, the use of natural compound as anticancer agents has gained a great deal of attention for their possible therapeutic qualities with minimal toxicity (6-9).

Some natural agents suppress the proliferation of cancer cells by inducing apoptosis (10). The expression of several genes has been demonstrated to be critical for the regulation of apoptosis such as Bcl-2 family proteins. The members of the Bcl-2 family play an important role in the regulation of the apoptotic pathway (11). In the Bcl-2 family members, Bcl-2 is the most important anti-apoptotic protein, whereas Bax is a pro-apoptotic protein (12). The ratio of Bax/Bcl-2 is critical for the induction of apoptosis and this ratio determines whether cells will undergo apoptosis (13).

MicroRNAs (miRNAs) are a kind of non-coding small RNAs that can post-transcriptionally regulate the expression of hundreds of their target genes $(14,15)$. miRNAs play an important role in diverse cellular processes, such as development, proliferation, differentiation and apoptosis $(16,17)$, some miRNAs act as oncogenes or tumor suppressors in tumorigenesis $(18,19)$. Recent evidence indicates that some anticancer agents suppress the proliferation of malignant cells by regulation expression of miRNAs (20-22).

Waltonitone (Fig. 1), an ursane-type pentacyclic triterpene isolated from Chinese medical plant Gentiana waltonii Burkill, has been shown to inhibit cell growth and induces cell apoptosis in human hepatocellular carcinoma (23). However, since the antitcancer effect of waltonitone in lung cancer is unknown, we explored the effect of waltonitone treatment in lung cancer A549 cells and investigated the mechanisms underlying the inhibitory effect of waltonitone in lung cancers.

\section{Materials and methods}

Reagents and chemicals. RPMI-1640, penicillin, streptomycin, and trypsin were purchased from Biological Industries (Kibbutz Beit Haemek, Israel). Fetal bovine serum (FBS) was purchased from Solarbio (Beijing Solarbio Science and Technology, China). 3-(4,5-Dimethyl thiazol-2yl)-2,5-diphe- 


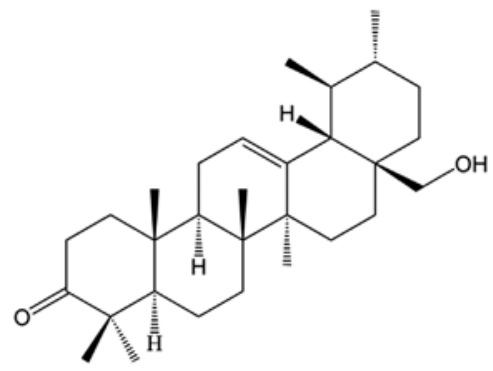

Figure 1. The structure of waltonitone.

nyltetrazolium bromide (MTT), dimethyl sulfoxide (DMSO) kit was purchased from Sigma-Aldrich (St. Louis, MO, USA). Annexin V-FITC and PI double staining kit were purchased from KeyGene (Nanjing, China). Waltonitone (HPLC purity $\geq 98 \%$ ) was purchased from Shanghai R\&D Centre for Standardization of Chinese Medicines (Shanghai, China). A $100-\mathrm{mM}$ stock solution of waltonitone was prepared in DMSO and stored at $-20^{\circ} \mathrm{C}$. Antibodies against $\mathrm{Bcl}-2$ and Bax were purchased from Santa Cruz Biotechnology (Santa Cruz, CA). Horseradish peroxidase-conjugated secondary antibody was obtained from Santa Cruz Biotechnology. TRIzol reagent was from Invitrogen (CA, USA). All other chemicals were obtained from Sinopharm Chemical Reagent Co., Ltd. (Shenyang, China).

Cell culture. A human lung cancer A549 cell line was obtained from the China Center for Type Culture Collection (Wuhan, China). A549 cells were cultured in RPMI-1640 supplemented with $10 \% \mathrm{FBS}, 100 \mathrm{U} / \mathrm{ml}$ penicillin, and $100 \mu \mathrm{g} / \mathrm{ml}$ streptomycin at $37^{\circ} \mathrm{C}$ in a humidified atmosphere of $5 \% \mathrm{CO}_{2}$. Culture medium was changed every day. Cells for assays were detached by a solution of $0.125 \%$ trypsin and $0.02 \%$ EDTA.

Cell viability assay. Viability was assessed by MTT assay. A549 cells were plated at a density of $1 \times 10^{4}$ cells per well in 96-well plates overnight. Cells were treated with different concentrations of waltonitone $(5,10,20,30,40$ and $50 \mu \mathrm{mol} / \mathrm{l})$. After exposure to waltonitone for $24,48,72 \mathrm{~h}$, $25 \mu \mathrm{l}$ of MTT solution ( $2 \mathrm{mg} / \mathrm{ml}$ in PBS) was added to each well and the plates were incubated for an additional $4 \mathrm{~h}$ at $37^{\circ} \mathrm{C}$. Then the medium was totally removed and $150 \mu \mathrm{l}$ of DMSO were added to each well to solubilize the formazan crystals formed in viable cells. Finally, the plates were shaken and the optical density was determined at $570 \mathrm{~nm}$ (OD570) using ELISA plate reader (Model 550, Bio-Rad, Laboratories, Hercules, CA, USA). This procedure was replicated three times.

Fluorescent microscopy. The morphology of apoptotic cells was detected by nuclear staining with Hoechst 33342. A549 cells $\left(5 \times 10^{5}\right)$ were grown on coverslips placed into 6-well plates overnight. Cells were treated with different concentrations of waltonitone ( 0 and $20 \mu \mathrm{mol} / \mathrm{l})$. After $24 \mathrm{~h}$, the cells were washed twice with cold PBS, then fixed with cold methanol and acetic acid $(3 / 1, \mathrm{v} / \mathrm{v})$ at $4{ }^{\circ} \mathrm{C}$ overnight and stained with Hoechst 33342 for 30 min in the dark, washed again in PBS and finally mounted in mounting medium (80\% glycerol in PBS). Processed cells were observed with a fluorescence microscope (Nikon, Japan).

Annexin V/PI flow cytometric analysis. The number of apoptotic cell death induced by waltonitone was measured by flow cytometry using Annexin V-FITC Apoptosis kit. Briefly, following treatment with waltonitone $(0,10,20$ and $30 \mu \mathrm{mol} / \mathrm{l})$ for $24 \mathrm{~h}, 1 \times 10^{6}$ cells were harvested by centrifugation $(1,000 \mathrm{rpm} / \mathrm{min})$, washed twice with cold PBS. The cell pellet was re-suspended in $1 \mathrm{X}$ binding buffer at a concentration of $1 \times 10^{6}$ cells $/ \mathrm{ml}$. Cell suspension $(100 \mu \mathrm{l})$ was transferred into FCM tube. Annexin V-FITC (5 $\mu \mathrm{l})$ and $10 \mu \mathrm{l}$ of PI were added into the cell suspension, followed by gentle vortexing. The cells were incubated at room temperature for $15 \mathrm{~min}$ in the dark. An additional $400 \mu \mathrm{l}$ of $1 \mathrm{X}$ binding buffer was added to each tube. The cells were analyzed using a FACScan flow cytometer and analyzed using CellQuest software (BectonDickinson, Redlands, CA).

Western blot analysis. The expression of apoptosis-related proteins was evaluated by western blot analysis. In brief, $3 \times 10^{7}$ cells were incubated with the designated doses of waltonitone $(0,10,20$ and $30 \mu \mathrm{mol} / \mathrm{l})$ for $24 \mathrm{~h}$. The cells were then washed in PBS and suspended in five volumes of lysis buffer (20 mM HEPES, pH 7.9, 20\% glycerol, $200 \mathrm{mM}$ $\mathrm{KCl}, 0.5 \mathrm{mM}$ EDTA, $0.5 \% \mathrm{NP} 40,0.5 \mathrm{mM}$ DTT, $1 \%$ protease inhibitor cocktail). Lysates were then collected and stored at $-20^{\circ} \mathrm{C}$ until further use. Supernatant protein concentration was determined by the Bradford method. Supernatant samples containing $40 \mu \mathrm{g}$ of total protein were resolved by SDS-PAGE gel depending on the target protein sizes, transferred to PVDF membranes by electroblotting, and probed with anti-Bax, anti-Bcl-2 and anti-actin. Membranes were incubated with horseradish peroxidase-conjugated secondary antibodies. Blots were developed using an ECL kit.

Microarray analysis of miRNA profiles. miRNA microarray was used to investigate the differentially expressed miRNAs in A549 cells after waltonitone treated. A549 cells were treated with waltonitone ( 0 and $30 \mu \mathrm{mol} / \mathrm{l})$. Total RNA was extracted from cells using TRIzol reagent $24 \mathrm{~h}$ after waltonitone treatment. Total RNA samples were analyzed by CapitalBio Corp. for miRNAs microarray experiments. The GeneChip miRNA Array containing probes complementary to 847 human miRNAs registered in miRBase 11.0. Experimental procedures were performed as described in detail on the website of CapitalBio (http://www.capitalbio.com). A miRNA was determined as differentially expressed if its expression change was $>1.5$-fold, and it was identified as significantly changed using the Significance Analysis of Microarrays method with FDR $<0.05$.

Classification and target prediction of miRNAs. The candidate target genes of miRNAs are predicted and analyzed by miRanda (http://www.ebi.ac.uk/enright-srv/microcosm/ htdocs/targets/v5/), PicTar (http://pictar.mdc-berlin.de/) and TargetScan (http://www.targetscan.org/), and we chose the genes found by all the three software as the miRNA targets. Then, human genes related to cell proliferation and apoptosis were selected from the Gene Ontology database (http:// 


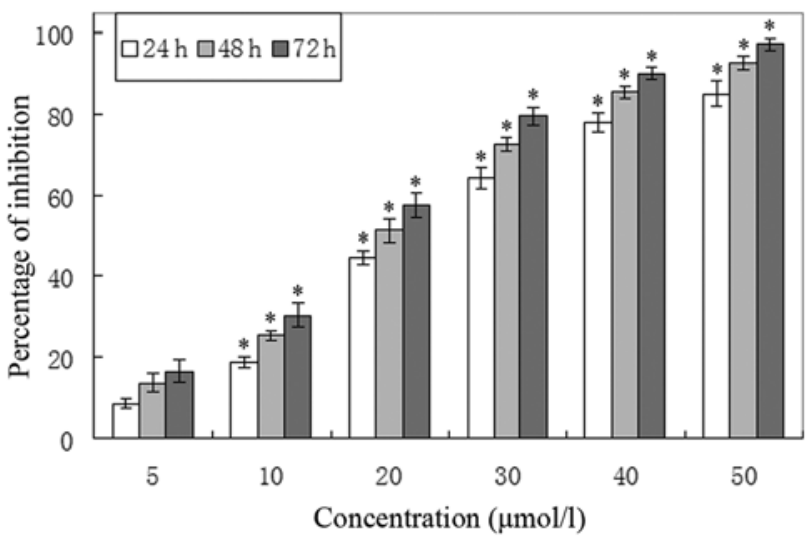

Figure 2. The proliferative inhibition effects of waltonitone on human lung cancer A549 cells. ${ }^{*} \mathrm{P}<0.05$ vs. control group.

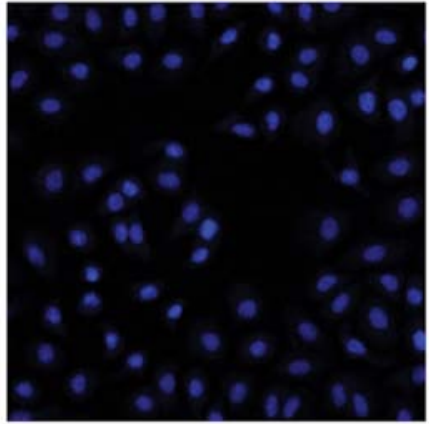

Control

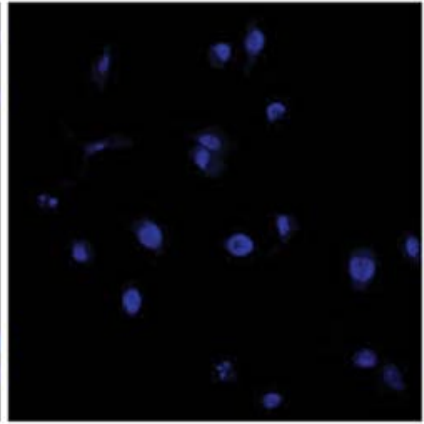

$20 \mu \mathrm{mol} / 1$
Figure 3. Cell apoptosis observed by Hoechst 33342 staining. A549 cells treated with $(0$ and $20 \mu \mathrm{mol} / \mathrm{l})$ of waltonitone for $24 \mathrm{~h}$. Apoptotic cells exhibited chromatin condensation, nuclear fragmentation and apoptotic bodies.

www. geneontology.org/), and the candidate genes predicted as targets of the miRNAs and those selected based on gene ontology were aligned by their gene names. Genes appearing in both lists were chosen and listed.

Statistical analysis. All experiments were conducted three times. Data were expressed as mean \pm SD. Statistical correlation of data was checked for significance by ANOVA and Student's t-test. The statistical significance was defined as $\mathrm{P}<0.05$. These analyses were performed using SPSS 11.0 software.

\section{Results}

Waltonitone inhibits A549 cell proliferation. In order to evaluate the growth inhibition effects of waltonitone on A549 cells, the cells were treated with various concentrations of waltonitone for 24, 48 and $72 \mathrm{~h}$. As shown in Fig. 2, waltonitone had significant growth inhibitory effects on A549 cells in a concentration- and time-dependent manner.

Waltonitone induces A549 apoptosis. Fluorescent microscopy analysis exhibited different morphological alterations in A549 cells after treatment with waltonitone ( 0 and $20 \mu \mathrm{mol} / \mathrm{l})$
A
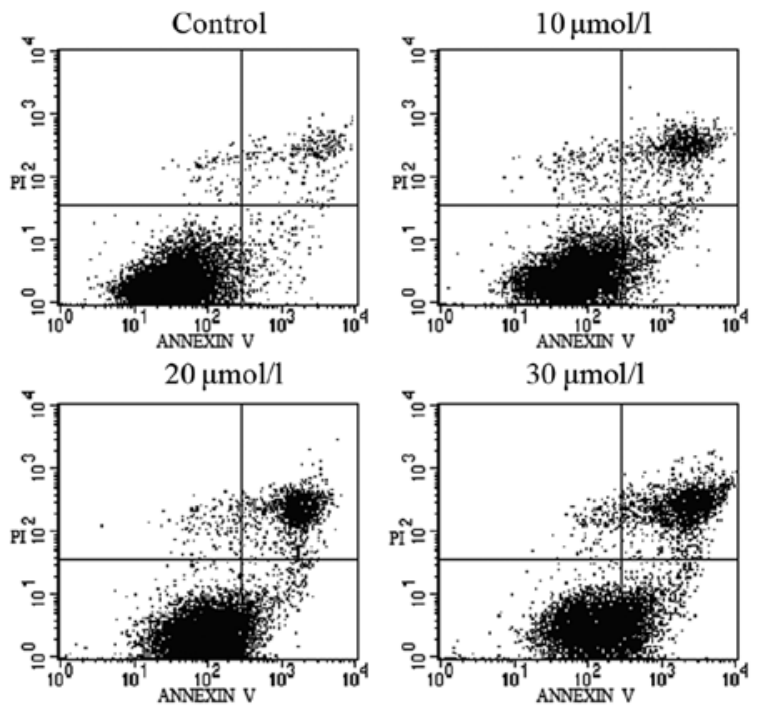

B

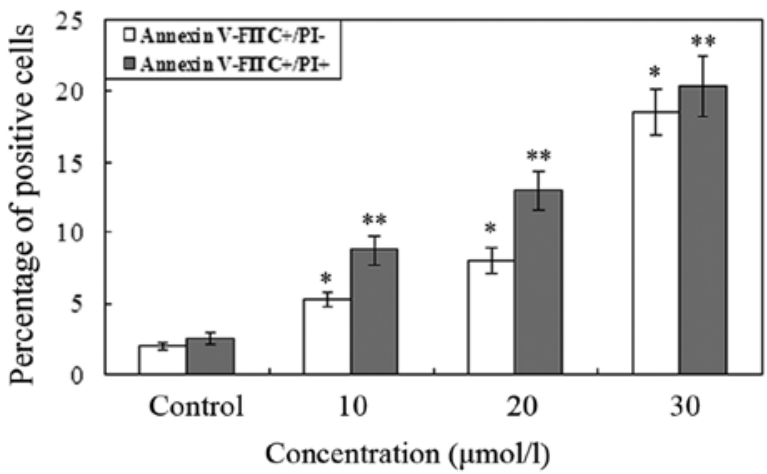

Figure 4. (A) Waltonitone-induced apoptosis in A549 cells as assayed by Annexin V/PI staining. A549 cells were treated with $(0,10,20$ and $30 \mu \mathrm{mol} / \mathrm{l})$ of waltonitone for $24 \mathrm{~h}$. The cells were then harvested and were stained with Annexin V/PI and flow cytometric analysis was performed to analyze apoptosis. (B) Summaries of the apoptosis data in histograms. ${ }^{*} \mathrm{P}<0.05$ vs. the control group (Annexin $\mathrm{V}$ positive); ${ }^{* *} \mathrm{P}<0.05$ vs. the control group (Annexin V and PI positive).

for $24 \mathrm{~h}$. As showed in Fig. 3, condensation of chromatin, nuclear fragmentations and apoptotic bodies were found clearly in treated A549 cells using Hoechst 33324 staining. The results showed that when exposed to waltonitone (20 $\mu \mathrm{mol} / \mathrm{l})$, A549 cells underwent the typical morphologic changes of apoptosis.

The number of apoptotic cell death induced by waltonitone was measured by Annexin V/PI staining. A549 cells were treated with different concentrations of waltonitone $(0,10,20$, and $30 \mu \mathrm{mol} / \mathrm{l}$ ) for $24 \mathrm{~h}$ and were analyzed by flow cytometry. As displayed in Fig. 4, the numbers of early and late apoptotic cells were significantly increased compared to control group. The results show that when treated with waltonitone for $24 \mathrm{~h}$, the ratio of apoptotic cells significantly increased in a concentration-dependent manner.

Waltonitone induced expression of apoptosis-related Bcl-2 family proteins. In order to understand the molecular basis of waltonitone-induced apoptosis, we investigated the expression levels of Bcl-2 and Bax by western blot analysis. The western blot analysis showed that waltonitone treatment leads to 


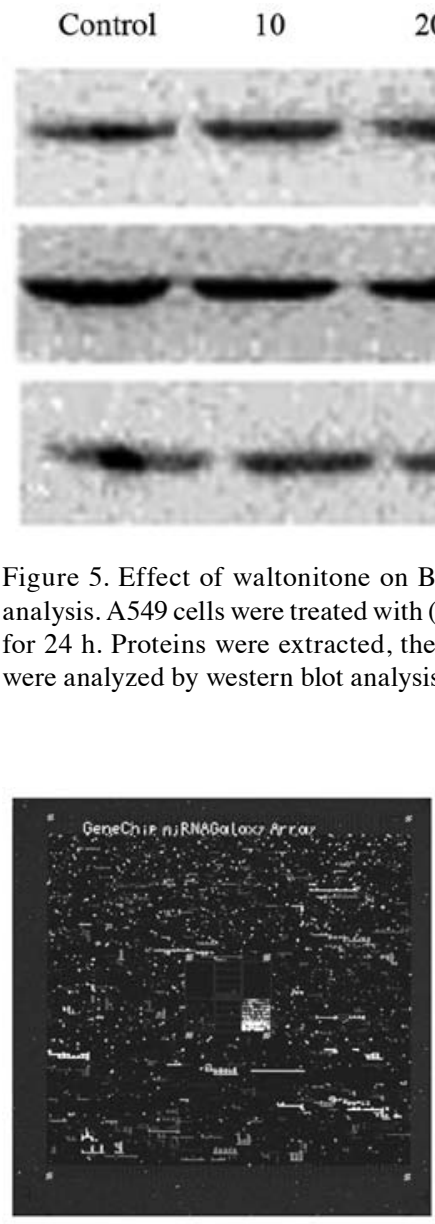

Control

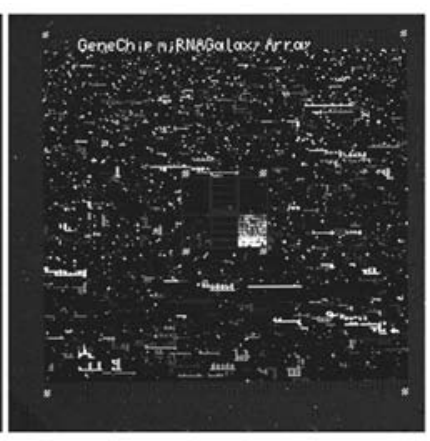

$30 \mu \mathrm{mol} / 1$
Figure 6. miRNA GeneChip showing changes after waltonitone exposure.

decrease in Bcl-2 levels; increase in Bax levels as compared to control cells (Fig. 5). The ratios of Bax/Bcl-2 increased as the concentration of waltonitone increased.

Waltonitone affects the expression of miRNAs. We investigated whether the treatment of cells with waltonitone could affect the expression of miRNAs. Using miRNA microarray analysis, we found 27 miRNAs with $>1.5$-fold expression changes in waltonitone-treated A549 cells (Fig. 6), of which 15 were upregulated, and 12 downregulated. A total of 27 miRNAs with expression levels regulated by waltonitone treatment (Table I) were selected to identify potential target genes related to cell proliferation and apoptosis.

Latent targets of each miRNA were predicted using miRanda, PicTar and TargetScan. We investigated related targets from the Gene Ontology database that were separated into two groups: cell proliferation and apoptosis. We found 26 genes associated with cell proliferation, and 26 genes associated with apoptosis (Table II) (Fig. 7).

\section{Discussion}

Lung cancer is the leading cause of cancer-related deaths in the world. It accounts for $17.6 \%$ of cancer death, and its 5-year
Table I. The 27 miRNAs showing 1.5-fold expression changes after waltonitone exposure.

\begin{tabular}{lc}
\hline miRNA name & Change-fold \\
\hline Upregulation & \\
hsa-miR-1246 & 3.461 \\
hsa-miR-663 & 2.513 \\
hsa-miR-1308 & 2.504 \\
hsa-miR-1225 & 1.844 \\
hsa-miR-21 & 1.764 \\
hsa-miR-346 & 1.739 \\
hsa-miR-29a & 1.728 \\
hsa-miR-720 & 1.624 \\
hsa-miR-1228 & 1.602 \\
hsa-miR-126 & 1.562 \\
hsa-miR-149 & 1.554 \\
hsa-miR-500 & 1.542 \\
hsa-miR-221 & 1.532 \\
hsa-miR-638 & 1.519 \\
hsa-miR-22 & 1.51 \\
Downregulation & \\
hsa-miR-455-3p & 1.501 \\
hsa-miR-371-5p & 1.524 \\
hsa-miR-10a & 1.526 \\
hsa-miR-324-3p & 1.536 \\
hsa-miR-18b & 1.538 \\
hsa-miR-186 & 1.543 \\
hsa-let-7c & 1.689 \\
hsa-miR-886-3p & 1.697 \\
hsa-miR-516a-5p & 1.745 \\
hsa-miR-411 & 1.754 \\
hsa-miR-18a & 1.919 \\
hsa-miR-324 & 2.481 \\
& \\
&
\end{tabular}

survival rate is only $8.9-15 \%(1,2,5)$. Lung cancer is generally classified into two histological types, small cell lung cancer and non-small cell lung cancer. Non-small cell lung cancer accounts for approximately $85 \%$ of the cases and it is further divided into squamous cell carcinoma, adenocarcinoma, large cell carcinoma, and others $(24,25)$. Despite advances in early detection and standard treatment, non-small cell lung cancer is often diagnosed at an advanced stage and has a poor prognosis (26). Chemotherapy plays an important role in the treatment of non-small cell lung cancer, but it is limited to a significant extent by its toxicities, drug resistance and significant side effects, including myelosuppression, neutropenia and thrombocytopenia $(3,4)$. One possible way to increase the efficacy of anticancer drugs and to decrease toxicities or side effects is to develop natural compounds, especially from medicinal plants.

Waltonitone, an ursane-type pentacyclic triterpene isolated from Chinese medical plant Gentiana waltonii Burkill, has been used for centuries in treatment of patients with various autoimmune diseases in China. Study has shown that it 
Table II. Classification and target prediction of miRNAs.

Functions of target genes

\begin{tabular}{lll}
\cline { 2 - 3 } miRNA name & \multicolumn{1}{c}{ Cell proliferation } & \multicolumn{1}{c}{ Apoptosis } \\
\hline hsa-let-7c & UHRF2, TUSC2, CDC25A, CBFA2T3 & DPF2, PLAGL2, BCL2L1 \\
hsa-miR-10a & MAPRE1, BCL6, PURB & BCL6, PURB \\
hsa-miR-126 & \multicolumn{1}{c}{-} & \\
hsa-miR-149 & PURB, BAI1, RAP1B & PURB, BCL2L2 \\
hsa-miR-186 & PURB, DLG5, PDGFC & EP300, PURB \\
hsa-miR-21 & JAG1, PURB, TGFBI, PITX2 & PURB, NTF3, RHOB \\
hsa-miR-22 & PURB, CUL3, PTEN, FOSL1 & LGALS1, PURB, SIRT1, PLAGL2, CUL3, YARS, PTEN \\
hsa-miR-221 & IRF2 & MAP3K10, PDCD10 \\
hsa-miR-29a & PPM1D, PDGFB, PMP22, LAMC1 & FEM1B, RYBP, BCL2L2, SGK, PPP2CA
\end{tabular}

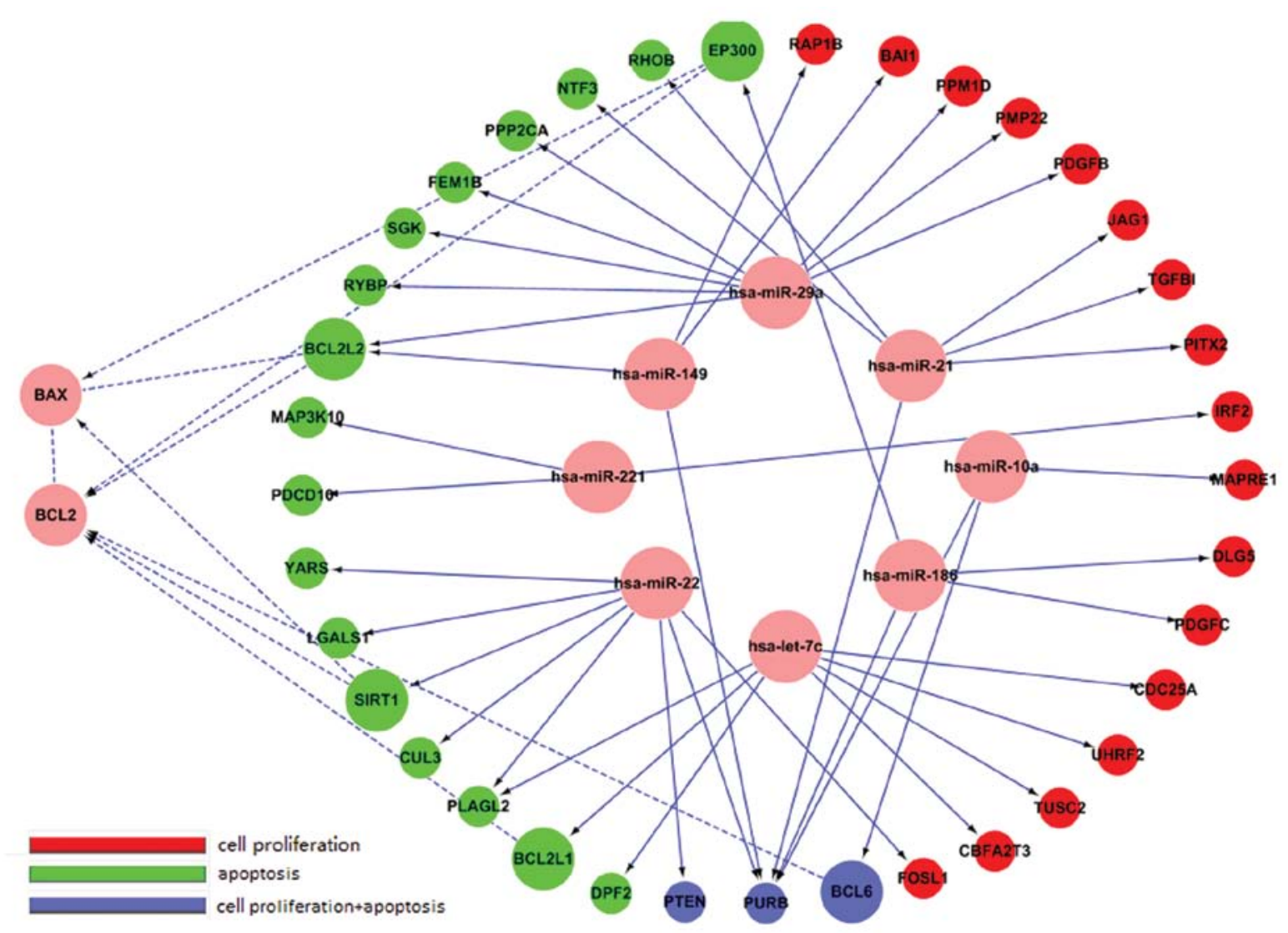

Figure 7. The relation of Bax/Bcl-2 and potential target genes.

inhibits growth of cultured cells and induces cell apoptosis in cancer cells (23). In this study, we first demonstrated that A549 cells treated with waltonitone showed a concentrationand time-dependent inhibition of the proliferation. Nuclear fragmentation, chromosome condensation and formation of apoptotic bodies were also observed by fluorescent microscopy. Flow cytometric analysis revealed that waltonitone treatment results in an increase of apoptotic cells. We observed the molecular basis of waltonitone-induced apoptosis by downregulation of $\mathrm{Bcl}-2$ protein levels and upregulation of Bax protein expression. Furthermore, the mechanism of waltonitone-inhibited proliferation involves the regulation of miRNAs.

The Bcl-2 family regulates the apoptotic pathway and can be divided into two types: anti-apoptotic proteins and proapoptotic proteins (11-13). Many anticancer agents extracted from Chinese herbs induce cancer cell apoptosis targeting the balance of pro- and anti-apoptotic proteins (27-29). Bcl-2 is an anti-apoptotic protein of the Bcl-2 family, and Bax is an proapoptotic protein. The ratio of $\mathrm{Bax} / \mathrm{Bcl}-2$ is a decisive factor and plays an important role in determining whether cells will undergo apoptosis. Our results showed that expression of $\mathrm{Bcl}-2$ 
was downregulated by waltonitone, whereas Bax expression was upregulated, leading to upregulation of the ratio between Bax and Bcl-2. This might contribute to the apoptosis promotion activity of waltonitone.

miRNAs are small non-coding RNA molecules that modulate the post-transcriptional regulation of gene expression in multi-cellular organisms by complementary interaction with the 3'-untranslated regions (3'-UTR) of target mRNA $(14,30,31)$. miRNA interaction influences protein expression by promoting the degradation or suppressing mRNA translation (15). The expression of miRNAs has been recognized as integral components of many biologic processes including cell proliferation, development, apoptosis and differentiation $(16,17)$. Recently, many studies have shown that miRNAs play an important role in the development and progression of cancers $(18,19)$. The miRNAs expression patterns could be potential biomarkers used for diagnosis, prognosis, and personalized therapy in cancer include non-small cell lung cancer (32-35). It is likely, therefore, that some anticancer agents suppress the proliferation of malignant cells by regulation expression of miRNAs (20-22). While altered expression of miRNAs has been the important application for discovering effective targets and mechanisms in treatment of cancer with natural compound.

To further understand the mechanisms of action of waltonitone against the growth of human lung cancer cells, we investigated the effects of waltonitone on the expression of miRNAs. Using miRNA microarray analysis, we found 27 miRNAs with $>1.5$-fold expression changes in waltonitonetreated A549 cells, 15 upregulated and 12 downregulated miRNAs. Furthermore, we identified potential target genes of these miRNAs related to cell proliferation and apoptosis. We found 26 genes associated with cell proliferation and 26 genes associated with apoptosis. Thus, waltonitone may inhibit proliferation and induce apoptosis of human lung cancer A549 cells through regulation of expression of miRNAs.

In conclusion, we demonstrated that waltonitone inhibited proliferation and promoted apoptosis in lung cancer A549 cells. This apoptotic response is associated with the upregulation of the ratio of $\mathrm{Bax} / \mathrm{Bcl}-2$. Moreover, modulation of miRNA expression may be an important mechanism underlying the biological roles of waltonitone. Based on the outcome of this study, we suggest that waltonitone, at least in part, inhibited proliferation of human lung cancer A549 cells through regulating expression of miRNAs. Waltonitone shows potential for development as an agent for the management of lung cancer.

\section{Acknowledgements}

The authors thank Dr Ting-Shu Jiang (Department of Respiratory Medicine, Shengjing Hospital of China Medical University) for experimental guidance.

\section{References}

1. Parkin DM, Bray F, Ferlay J and Pisani P: Global cancer statistics, 2002. CA Cancer J Clin 55: 74-108, 2005.

2. Jemal A, Siegel R, Ward E, Hao Y, Xu J, Murray T and Thun MJ: Cancer statistics, 2008. CA Cancer J Clin 58: 71-96, 2008.
3. Chau GY, Lui WY, Tsay SH, Chao Y, King KL and Wu CW: Postresectional adjuvant intraportal chemotherapy in patients with hepatocellular carcinoma: a case-control study. Ann Surg Oncol 13: 1329-1337, 2006.

4. Ono T, Yamanoi A, Nazmy El Assal O, Kohno H and Nagasue N: Adjuvant chemotherapy after resection of hepatocellular carcinoma causes deterioration of long-term prognosis in cirrhotic patients: metaanalysis of three randomized controlled trials. Cancer 91: 2378-2385, 2001.

5. Erridge SC, Moller H, Price A and Brewster D: International comparisons of survival from lung cancer: pitfalls and warnings. Nat Clin Pract Oncol 4: 570-577, 2007.

6. Reyes-Zurita FJ, Rufino-Palomares EE, Lupianez JA and Cascante M: Maslinic acid, a natural triterpene from Olea europaea L., induces apoptosis in HT29 human colon-cancer cells via the mitochondrial apoptotic pathway. Cancer Lett 273: 44-54, 2009.

7. Moghaddam SJ, Barta P, Mirabolfathinejad SG, AmmarAouchiche Z, Garza NT, Vo TT, Newman RA, Aggarwal BB, Evans CM, Tuvim MJ, et al: Curcumin inhibits COPD-like airway inflammation and lung cancer progression in mice. Carcinogenesis 30: 1949-1956, 2009.

8. Harikumar KB, Kunnumakkara AB, Sethi G, Diagaradjane P, Anand P, Pandey MK, Gelovani J, Krishnan S, Guha S and Aggarwal BB: Resveratrol, a multitargeted agent, can enhance antitumor activity of gemcitabine in vitro and in orthotopic mouse model of human pancreatic cancer. Int J Cancer 127: 257-268, 2010.

9. Sukhthankar M, Yamaguchi K, Lee SH, McEntee MF, Eling TE, Hara Y and Baek SJ: A green tea component suppresses posttranslational expression of basic fibroblast growth factor in colorectal cancer. Gastroenterology 134: 1972-1980, 2008.

10. Xavier CP, Lima CF, Preto A, Seruca R, Fernandes-Ferreira M and Pereira-Wilson C: Luteolin, quercetin and ursolic acid are potent inhibitors of proliferation and inducers of apoptosis in both KRAS and BRAF mutated human colorectal cancer cells. Cancer Lett 281: 162-170, 2009.

11. Burlacu A: Regulation of apoptosis by Bcl-2 family proteins. J Cell Mol Med 7: 249-257, 2003.

12. Metrailler-Ruchonnet I, Pagano A, Carnesecchi S, Ody C, Donati $\mathrm{Y}$ and Barazzone Argiroffo $\mathrm{C}$ : $\mathrm{Bcl}-2$ protects against hyperoxia-induced apoptosis through inhibition of the mitochondria-dependent pathway. Free Radic Biol Med 42: 1062-1074, 2007.

13. Yao Y, Huang C, Li ZF, Wang AY, Liu LY, Zhao XG, Luo Y, Ni L, Zhang WG and Song TS: Exogenous phosphatidylethanolamine induces apoptosis of human hepatoma HepG2 cells via the bcl-2/ Bax pathway. World J Gastroenterol 15: 1751-1758, 2009.

14. Pillai RS, Bhattacharyya SN and Filipowicz W: Repression of protein synthesis by miRNAs: how many mechanisms? Trends Cell Biol 17: 118-126, 2007.

15. Ambros $V$ and Chen $X$ : The regulation of genes and genomes by small RNAs. Development 134: 1635-1641, 2007.

16. Ambros V: MicroRNA pathways in flies and worms: growth, death, fat, stress, and timing. Cell 113: 673-676, 2003.

17. Calin GA, Dumitru CD, Shimizu M, Bichi R, Zupo S, Noch E, Aldler H, Rattan S, Keating M, Rai K, et al: Frequent deletions and down-regulation of micro-RNA genes miR15 and miR16 at 13q14 in chronic lymphocytic leukemia. Proc Natl Acad Sci USA 99: $15524-15529,2002$.

18. Chen CZ: MicroRNAs as oncogenes and tumor suppressors. N Engl J Med 353: 1768-1771, 2005.

19. Wang D, Qiu C, Zhang H, Wang J, Cui Q and Yin Y: Human microRNA oncogenes and tumor suppressors show significantly different biological patterns: from functions to targets. PLoS One 5: e13067, 2010.

20. Rossi L, Bonmassar E and Faraoni I: Modification of miR gene expression pattern in human colon cancer cells following exposure to 5-fluorouracil in vitro. Pharmacol Res 56: 248-253, 2007.

21. Li Y, VandenBoom TG II, Kong D, Wang Z, Ali S, Philip PA and Sarkar FH: Up-regulation of miR-200 and let-7 by natural agents leads to the reversal of epithelial-to-mesenchymal transition in gemcitabine-resistant pancreatic cancer cells. Cancer Res 69: 6704-6712, 2009.

22. Tili E, Michaille JJ, Adair B, Alder H, Limagne E, Taccioli C, Ferracin M, Delmas D, Latruffe N and Croce CM: Resveratrol decreases the levels of miR-155 by upregulating miR-663, a microRNA targeting JunB and JunD. Carcinogenesis 31: 1561-1566, 2010 
23. Zhang Z, Wang S, Qiu H, Duan C, Ding K and Wang Z: Waltonitone induces human hepatocellular carcinoma cells apoptosis in vitro and in vivo. Cancer Lett 286: 223-231, 2009.

24. Brambilla E, Travis WD, Colby TV, Corrin B and Shimosato Y: The new World Health Organization classification of lung tumours. Eur Respir J 18: 1059-1068, 2001.

25. Wistuba II and Gazdar AF: Lung cancer preneoplasia. Annu Rev Pathol 1: 331-348, 2006.

26. Herbst RS, Heymach JV and Lippman SM: Lung cancer. N Engl J Med 359: 1367-1380, 2008.

27. Pongrakhananon V,Nimmannit U, Luanpitpong S, Rojanasakul Y and Chanvorachote P: Curcumin sensitizes non-small cell lung cancer cell anoikis through reactive oxygen species-mediated Bcl-2 downregulation. Apoptosis 15: 574-585, 2010.

28. Jiang T, Zhou L, Zhang W, Qu D, Xu X, Yang Y and Li S: Effects of sinomenine on proliferation and apoptosis in human lung cancer cell line NCI-H460 in vitro. Mol Med Rep 3: 51-56, 2010.

29. Ren G, Zhao YP, Yang L and Fu CX: Anti-proliferative effect of clitocine from the mushroom Leucopaxillus giganteus on human cervical cancer HeLa cells by inducing apoptosis. Cancer Lett 262: $190-200,2008$
30. Luthra R, Singh RR, Luthra MG, Li YX, Hannah C, Romans AM, Barkoh BA, Chen SS, Ensor J, Maru DM, et al: MicroRNA196a targets annexin A1: a microRNA-mediated mechanism of annexin A1 downregulation in cancers. Oncogene 27: 6667-6678, 2008.

31. Raver-Shapira N, Marciano E, Meiri E, Spector Y, Rosenfeld N, Moskovits N, Bentwich Z and Oren M: Transcriptional activation of miR-34a contributes to p53-mediated apoptosis. Mol Cell 26: 731-743, 2007.

32. Yanaihara N, Caplen N, Bowman E, Seike M, Kumamoto K, Yi M, Stephens RM, Okamoto A, Yokota J, et al: Unique microRNA molecular profiles in lung cancer diagnosis and prognosis. Cancer Cell 9: 189-198, 2006.

33. Yu SL, Chen HY, Chang GC, Chen CY, Chen HW, Singh S, Cheng CL, Yu CJ, Lee YC, Chen HS, et al: MicroRNA signature predicts survival and relapse in lung cancer. Cancer Cell 13: 48-57, 2008.

34. Ventura A and Jacks T: MicroRNAs and cancer: short RNAs go a long way. Cell 136: 586-591, 2009.

35. Raponi M, Dossey L, Jatkoe T, Wu X, Chen G, Fan H and Beer DG: MicroRNA classifiers for predicting prognosis of squamous cell lung cancer. Cancer Res 69: 5776-5783, 2009. 